九州大学学術情報リポジトリ

Kyushu University Institutional Repository

\title{
Application of the Direct Colony TLC for Identification of Phytopathogenic Bacteria (II) Chromatographic Profile of Erwinia and Pseudomonas spp.
}

Matsuyama, Nobuaki

Laboratory of Plant Pathology, Faculty of Agriculture, Kyushu University

Furuya, Naruto

Laboratory of Plant Pathology, Faculty of Agriculture, Kyushu University

https://doi.org/10.5109/24041

出版情報: 九州大学大学院農学研究院紀要. 38 (1/2)，pp.89-95，1993-12. Kyushu University バージョン：

権利関係 : 


\title{
Application of the Direct Colony TLC for Identification of Phytopathogenic Bacteria (II) Chromatographic Profile of Erwinia and Pseudomonas spp.
}

\author{
Nobuaki Matsuyama and Naruto Furuya \\ Laboratory of Plant Pathology, Faculty of Agriculture, \\ Kyushu University 46-01, Fukuoka 812, Japan. \\ (Received July 23, 1993)
}

\begin{abstract}
A rapid identification of phytopathogenic bacteria was available at species level by the direct colony thin-layer chromatography. Distinct difference was observed in chromatographic profile between Erwinia chrysanthemi and E. carotovora subsp. carotovora. In the case of Erwinia carotovora subsp. carotovora, a characteristic spot at $\mathrm{Rf} 0.57$ appeared concomitantly with a common spot at 0.62 . The chromatograms of Pseudomonas spp. were divided into three major types. The chromatograms of P. gladioli pv. gladioli, P. glumae, $P$. plantarii, P.caryophylli and $P$. cepacia resembled each other. This chromatographic profile was clearly different from those of other pseudomonads and designated as a Cepacia-type. In the case of $P$. solanacearum, a characteristic spot appeared at $\mathrm{Rf} 0.54$ and this profile was named as a Solanacearum-type. The profile of remaining pseudomonads was simple and similar each other, and was designated as a Syringae-type. A practical usefulness of this easy method was certified also in this experiment.
\end{abstract}

\section{INTRODUCTION}

In 1986, an easy method for identification of lipids from bacterial whole cells was invented by Matsuyama et al. and used for the lipid-analyses of Serratia spp. (Matsuyama et al., 1986, 1987). This method is one-dimentional TLC but involves two steps of the development with two kinds of developing-solvent systems. The first development with chloroform-methanol $(\mathrm{CM}, 2: 1, \mathrm{v} / \mathrm{v})$ for short time $(10 \mathrm{~min})$ is conducted for the extraction of lipids from bacterial whole cells which were pasted directly on silica gel TLC plate. The second development with chloroform-methanolwater (CMW, 60:25:4, v/v/v) was conducted for the separation of lipids extracted by the first development with CM solvent-system. Recently, the authors applied this method for the distinction of the phytopathogenic bacteria (Matusyama et al., 1993a, b, c) and verified its practical usefulness for a rapid identification of bacteria. In these former experiments, we found that this procedure was avairable for the distinction of bacteria at generic level and in some cases at species level. To certify these results, the comparison with more isolates was conducted.

\section{MATERIALS AND METHODS}

\section{Bacterial strains used}

Fifty-nine isolates of Erwinia and Pseudomonas spp. which were originally donated 
Table 1. Erwinia species used in this experiment.

\begin{tabular}{|c|c|c|}
\hline Erwinia spp. & Isolates & Source \\
\hline E. chrysanthemi pv. chrysanthemi & Ku8601 L1 & $\mathrm{AKU}$ \\
\hline$n$ & Ichihara $1-1$ & TUA \\
\hline pv. zeae & Corn 801 & $\mathrm{~s} \mathrm{u}$ \\
\hline pv. unidentified & Ech 44 & $\mathrm{AKU}$ \\
\hline E. carotovora subsp. carotovora & EH8519 & NIAS \\
\hline$\eta$ & N7101 & $n$ \\
\hline$\eta$ & $473-1$ & LSPPM \\
\hline$n$ & $489-4$ & "l \\
\hline$\eta$ & $493-1$ & 1) \\
\hline$\eta$ & $645 \mathrm{ar}$ & IU \\
\hline E. herbicola pv. milletiae & 1 & NIAS \\
\hline
\end{tabular}

NIAS: National Institute of Agricultural Sciences, Tokyo, Japan.

(This Institute was reconstructed partly to NIAES)

NIAES: National Institute of Agro-Environmental Sciences, Tsukuba, Japan.

AKU: Faculty of Agriculture, Kyushu University, Fukuoka, Japan.

TUA: Tokyo University of Agriculture, Tokyo, Japan.

SU: Faculty of Agriculture, Shizuoka University, Shizuoka, Japan.

LSPPM: Laboratory of Seed and Post-harvest Disease, Plant Pathology and

Microbiology Division, Department of Agriculture, Bangkok, Thailand.

IU: Faculty of Agriculture, Iwate University, Morioka, Japan.

from various institutes and have been kept in author's laboratory were used in this experiment (Table 1,2).

\section{Culture medium}

King B medium (EIKEN Chemical Co.) was used in this experiment. The ingredient of this medium was as follows : $20.0 \mathrm{~g}$ peptone, $1.5 \mathrm{~g} \mathrm{~K} \mathrm{KPO}_{4}, 1.5 \mathrm{~g}$

$\mathrm{MgSO}_{4} \cdot 7 \mathrm{H}_{2} \mathrm{O}, 15.0 \mathrm{~g}$ agar, 11 of $1 \%$ glycerol solution, $\mathrm{pH} 7.2$.

\section{Culture conditions}

Each bacterial isolate was cultured routinely at $30^{\circ} \mathrm{C}$ for 3 days on a slant of the medium stated above.

\section{Thin-layer chromatography}

The procedures of the direct colony thin-layer chromatography with CMW solventsystem and conditions for practice were shown elsewhere (Matsuyama $e l$ al., 1993b, c).

One loopful bacterial colony was taken from the slants stated above and pasted directly on the origins of the silica gel G TLC plate (Merck Co., Si60,20 x 20 cm or 10 $x 20 \mathrm{~cm}, \mathbf{0 . 2 5} \mathbf{m m}$ in thickness) and dried completely. The silica gel plate was developed with chloroform-methanol $(\mathrm{CM}, 2: 1, \mathrm{v} / \mathrm{v})$ in well-moistured rectungular glass tank. This first development was performed for only $10 \mathrm{~min}$ until the solvent front will reach $6 \mathrm{~cm}$ line from the origin spots. By this first development for a short time, the extraction of lipids from whole bacterial cells was carried out. Then, the plate was dried well and the bacterial cells pasted on the plate were scraped out. The plate was 
Table 2. Pseudomonas species used in this experiment.

\begin{tabular}{|c|c|c|}
\hline Pseudomonas spp. & Isolates & Source \\
\hline P. aeruginosa & IAM1054 & NIAS \\
\hline P. aureofaciens & IAM1001 & $n$ \\
\hline \multirow[t]{3}{*}{$P$. avenue } & H8206 & HNAES \\
\hline & $\mathrm{H} 8210$ & ง \\
\hline & $\mathrm{H} 8505$ & $n$ \\
\hline P. azo toformans & IAM1603 & NIAS \\
\hline \multirow[t]{2}{*}{ P. caryophylli } & NIAS1192 & ) \\
\hline & NIAS1406 & Jง \\
\hline \multirow[t]{3}{*}{ P. cepacia } & $243-4$ & נง \\
\hline & $256-3$ & 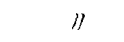 \\
\hline & $356-5$ & лง \\
\hline P. conjac & $\mathrm{b}-1$ & jง \\
\hline$P$. cruciviae & IAM1048 & l) \\
\hline P. fragi & IAM1650 & נง \\
\hline P. gladioli pv. gladioli & NIAS1064 & $n$ \\
\hline \multirow[t]{4}{*}{ J } & NIAS1065 & נง \\
\hline & E-14 & $\mathrm{AKU}$ \\
\hline & $251-17$ & NIAS \\
\hline & $251-20$ & /I \\
\hline \multirow[t]{3}{*}{ P. glumae } & 2 & KNAES \\
\hline & Kyu82-34-2 & I) \\
\hline & N7503 & NIAS \\
\hline P. jaegeri & IAM1008 & jง \\
\hline P. marginalis pv. marginalis & & נง \\
\hline$P$. melanogenum & IAM1554 & $n$ \\
\hline P. mildenbergii & IAM1505 & jง \\
\hline$P$. ovalis & IAM1002 & 》) \\
\hline P.plantarii (Type strain) & AZ8201 & HNAES \\
\hline P. polycolar & IF03918 & NIAS \\
\hline P. putida & IAM1506 & n \\
\hline$P$. rugosa & Pl-15-1 & נง \\
\hline \multirow{7}{*}{ P. solanacearum } & 6509 & y) \\
\hline & 6511 & נง \\
\hline & 6515 & 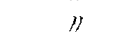 \\
\hline & 6277 & $m$ \\
\hline & Ku7502-1 & $\mathrm{AKU}$ \\
\hline & C319-SR & KTES \\
\hline & BY -4 & ") \\
\hline P. syringae pv. aptata & MAFF301008 & NIAS \\
\hline P. s. pv. atrofaciens & & ) \\
\hline P. s. pv. eriobotryae & I & ") \\
\hline P. s. pv. mori & & $n$ \\
\hline P. s. pv. striafaciens & & n \\
\hline P. s. pv. syringae (oryzicola) & & נง \\
\hline$P$. s.pv. syringae & 1 & נJ \\
\hline \multirow{2}{*}{ P. s. pv. tabaci } & Ku7103 & נл \\
\hline & MAFF301074 & ") \\
\hline P. vendrelli & & נл \\
\hline
\end{tabular}

NIAS, AKU: See the note of Table 1.

KNAES: Kyushu National Agricultural Experiment Station, Kumamoto, Japan. HNAES: Hokuriku National Agricultural Experiment Station, Takada, Japan. KTES: Kagoshima Tobacco Experiment Station, Kagoshima, Japan. 
developed once more at the same direction with other solvent-system, chloroformmethanol-water $(\mathrm{CMW}, 60: 25: 4, \mathrm{v} / \mathrm{v} / \mathrm{v}>$ for ca. $1.5 \mathrm{hr}$. Whole processes were conducted at $25^{\circ} \mathrm{C}$ in the incubator. Then, the plate was dried well and sprayed with ninhydrin (Ninhydrin spray, Tokyo Kasei Chemical Co.). Spots appeared on the plate by heating at $100^{\circ} \mathrm{C}$ for $10 \mathrm{~min}$ were recorded by a photograph and photocopy (Canon Co. FC-311).

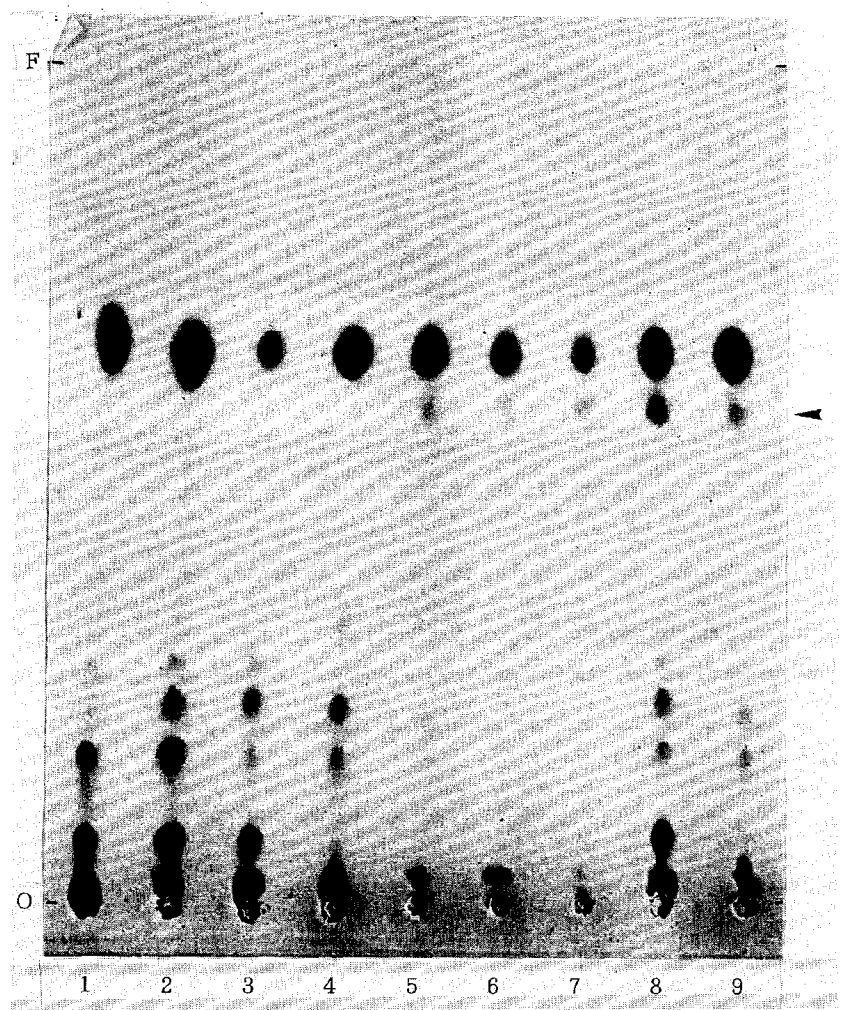

Fig. 1. TLC chromatogram of lipids from phytopathogenic bacteria. 1: Erwinia chrysanthemi pv. chrysanthemi Ku8601 L1

\begin{tabular}{|c|c|c|c|}
\hline 2: & 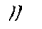 & ) & Ichihara \\
\hline 3: & $n$ & pv. zeae & Corn 801 \\
\hline 4: & "I & pv. unidentified & Ech 44 \\
\hline \multicolumn{3}{|c|}{ 5: $E$. carotovora subsp. carotovora } & $489-4$ \\
\hline 6: & ") & & $493-l$ \\
\hline 7: & ") & & N7101 \\
\hline 8: & $n$ & & 645ar \\
\hline 9: & $n$ & & $473-1$ \\
\hline
\end{tabular}

Each spot was visualized by ninhydin with successive heating at $100^{\circ} \mathrm{C}$ for $10 \mathrm{~min}$.

Arrow-head at right-side indicates a benchmark of E. carotovora subsp. carotovora.

F: Solvent front, 0: Origin 


\section{RESULTS AND DISCUSSION}

The results were shown in Fig. 1, 2, 3. The chromatographic profiles of phytopathogenic bacteria were different at species level.

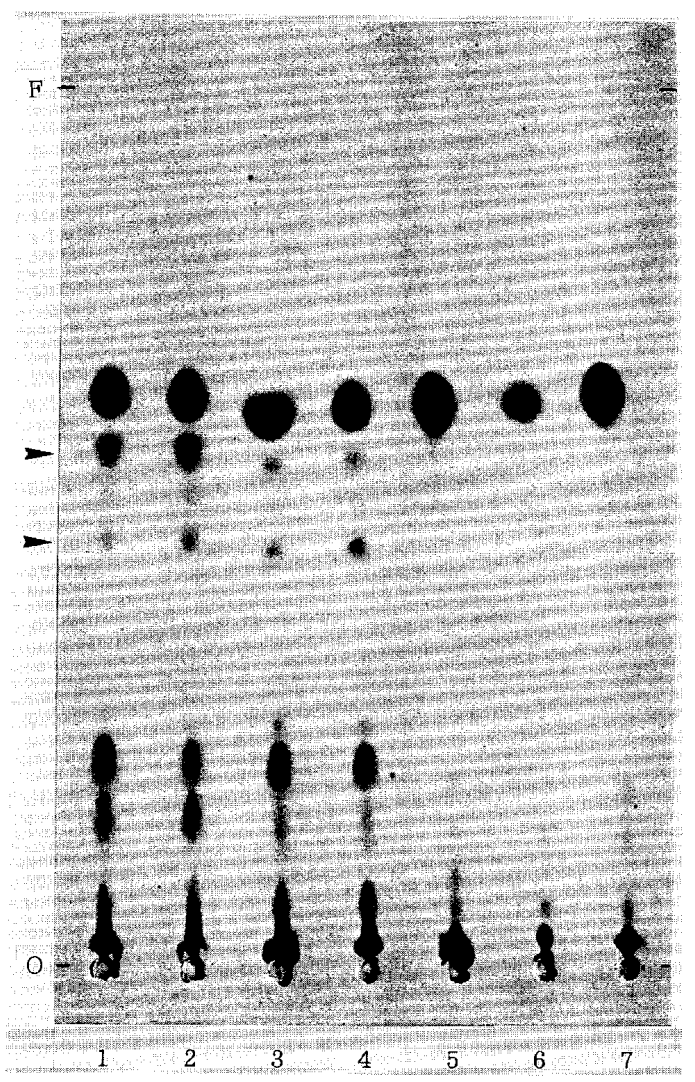

Fig. 2. TLC chromatogram of lipids from phytopathogenic bacteria.

$\begin{array}{lllr}\text { 1: } \text { Pseudomonas gladioli pv. gladioli } & \text { NIAS1064 } \\ \text { 2: } & \text { NIAS1065 } \\ \text { 3: } & \| & \text { glumae } & \text { N7503 } \\ \text { 4: } & \prime \prime & \text { "l } & 2 \\ \text { 5: } & \prime \prime & \text { syringae pv. syringae } & 1 \\ 6: & \prime \prime & \text { conjac } & \text { b-1 } \\ \text { 7: JJ } & \text { syringae pv. tabaci } & \text { Ku7103 }\end{array}$

Each spot was visualized by ninhydrin with successive heating at $100^{\circ} \mathrm{C}$ for $10 \mathrm{~min}$.

Arrow-heads at left-side indicate benchmarks of a Cepacia-type pseudomonads.

F: Solvent front, 0: Origin 
In the case of Erwinia spp., the distinct diversity of chromatograms was observed between Erwinia carotouora subsp. carotouora and E. chrysanthemi at species level. This result agreed well with author's results by gas-liquid chromatography (Kori et al., 1992). A characteristic spot at $\mathrm{Rf} 0.57$ (arrow-head at right margin of Fig. 1) was always detected on the chromatogram of Envinia carotouora subsp. carotovora. While, no differences were observed between $E$. chrysanthemi and $E$. herbicola pv. milletiae, or

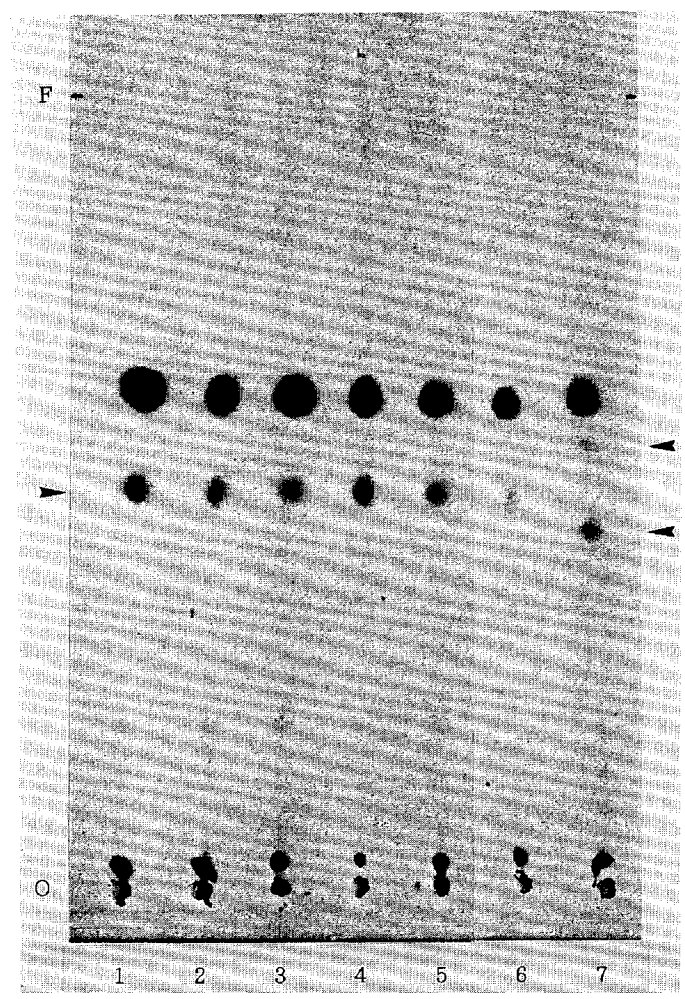

Fig. 3. TLC chromatogram of lipids from phytopathogenic bacteria.

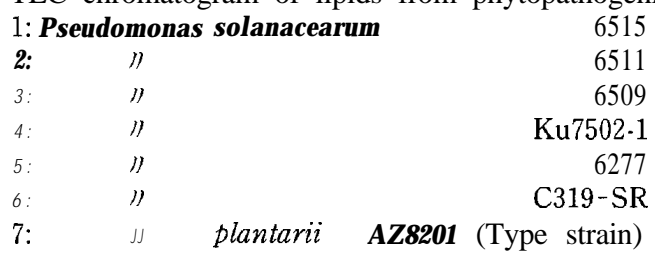

Each spot was visualized by ninhydrin with successive heating at $100^{\circ} \mathrm{C}$ for $10 \mathrm{~min}$.

Arrow-head at left-side indicates the benchmark spot of $\mathbf{P}$. solanacearum and two arrow-heads at right-side indicate those of a Cepacia-type pseudomonads.

F: Solvent front, 0: Origin 
among the pathovars of E. chrysanthemi. The distinction of pseudomonads at species level was available among some species. As can be seen in Fig. 2 and 3, the chromatograms of P. glumae, P. gladioli pv. gladioli, P. plantarii, P. cepacia and P. caryophylli were similar each other and different from those of other pseudomonads. This type of the chromatogram was designated as a Cepacia-type. In the case of $P$. solanacearum, a distinct spot was detected at Rf 0.54 (arrow-head at left margin of Fig. 3 ). This spot will be a benchmark of $P$. solanacearum and this chromatographic profile was designated as a Solanacearum-type. Most chromatograms of pseudomonads other than the species stated above were quite simple and only a common major spot at $\mathrm{Rf}$ 0.62 was observed except for minor spots below ca. Rf 0.30. This type of the chromatogram was designated as a Syringae-type. In former experiment with other solvent-system, chloroform-methanol-5M ammonia (CMA, 60:25:4, v/v/v), V-shaped abnormal spots appeared in the case of P. solanacearum. Such troubles disappeared by the substitutions of solvent-system CMW for CMA and KB medium for PSA (potato semisynthetic medium). The complete drying of bacterial cells which were pasted on the TLC plate with hair-drier followed by keeping in desiccator gave a preferable result, especially in the case of $P$. solanacearum and $P$. avenue.

This direct colony thin-layer chromatography was easy to practice and showed well reproducibility. Although this method is not always applicable to the distinction of all phytopathogenic bacteria at species level, it will be useful mean for a rapid identification and systematic classification of phytopathogenic bacteria.

\section{REFERENCES}

Kori, Y., N. Furuya, K. Tsuno and N. Matsuyama 1992 Differentiation of Erwinia chrysanthemi and E. carotovora by the cellular fatty acid analysis. J.Fac. Agric. Kyushu Univ., 37 (2): 173 178

Matsuyama, N., Ismail Hossain Mian, Abdul Mannan Akanda and N. Furuya 1993a Application of the direct colony TLC method for identification of phytopathogenic bacteria. J.Fac. Agr. Kyushu Univ., 3’7 (3・4): 281-285

Matsuyama, N., Ismail Hossain Mian, Abdul Mannan Akanda and N. Furuya 1993b Rapid identification of phytopathogenic bacteria by the direct colony thin - layer chromatography (1). Proc. Assoc. PI. Prot. Kyushu, 39: 60-64

Matsuyama, N., Ismail Hossain Mian, Abdul Mannan Akanda and N. Furuya 1993c Comparative studies on thin-layer chromatograms of lipids from various phytopathogenic bacteria. Ann. Phytopath. Soc. Japan, 58: 515-521

Matsuyama, T., M. Sogawa, K. Kaneda and I. Yano 1986 Rapid detection and identification of bacterial lipids by direct colony thin -layer chromatography. Proc. of 23rd international symposium of advances in chromatography, Chiba, Japan, pp. 1277128

Matsuyama, T., M. Sogawa and I. Yano 1987 Direct colony thin - layer chromatography and rapid characterization of Serratia marcescens mutants defective in production of wetting agents. Appl. Environ. Microbiol., 53: 1186-1188 